\title{
Unerroric Automatic Control of Civil Hydroacousticer's Working Quality on Board
}

\author{
Adeliya Yu. Burova, Vitaly V. Kabakov \\ Moscow Aviation Institute (National Research University), Volokolamskoe Highway 4, \\ 125993, Moscow, Russia
}

\begin{abstract}
The collision of a dry cargo ship with a submarine off Cape Ashizuri this year has actualized the study of the possibility of unerroric control of readiness of passenger and merchant ships to extreme variants of hydroacoustic conditions. The purpose of the research is to develop digital methods and algorithms of automatic quality control of ship's hydroacousticer. The possibility of such control by multilevel estimation of results within training hydroacousticer on board of the ship is investigated. Recurrent methods and algorithms of formation of final and intermediate estimations of results of such training in a training mode within functioning of on board hydroacoustic means are offered and developed. These methods and algorithms allow complicating the simulation model of hydroacoustic environment fraught with ship accidents.
\end{abstract}

Keywords - unerroric control; work quality; multilevel evaluation; ship's hydroacousticer; digital methods.

\section{Introduction}

The so-called "human factor" becomes more and more often the reason of unexpected failures of the sea

DOI: 10.18421/TEM111-41

https://doi.org/10.18421/TEM111-41

Corresponding author: Adeliya Yu. Burova,

Moscow Aviation Institute (National Research University),

Moscow, Russia.

Email: adeliya yu burova@mail.ru

Received: 09 November 2021.

Revised: 02 February 2022.

Accepted: 08 February 2022.

Published: 28 February 2022.

(cc) BY-Nc-ND (C) 2022 Adeliya Yu. Burova \& Vitaly V. Kabakov; published by UIKTEN. This work is licensed under the Creative Commons AttributionNonCommercial-NoDerivs 4.0 License.

The article is published with Open Access at https://www.temjournal.com/ passengers and trade transportations along with damage and technical malfunction of civil transport vehicles [1], [2]. Unpreparedness of ship crew to unlikely and extreme events sometimes leads to multimillion losses for business of regional trading corporations and trading firms of different countries. This results in significant price increases for various goods and services for which the consumers of them ultimately pay [3], [4].

Collision of commercial vessel "Ocean Artemis" with a submarine near Cape Ashizuri island of Shikoku not far from the coast of Japanese prefecture Kochi this year has actualized research of additional possibilities of unerroric control of readiness of ship's hydroacousticer of passenger liners, fishing seiners and commercial vessels to assess extreme variants of hydroacoustic situation taking into account hydroacoustic interference and noise emission of hydrobiota in different regions of the World Ocean [5], [6]. This control can and should be carried out by automatic estimation of results of training of the ship's hydroacousticer directly on board using hydroacoustic means of a vessel in a training mode of their functioning. Digital methods and algorithms of such evaluation are necessary and sufficient to be implemented on digital signal processors and programmable logic devices from the hardware of on board hydroacoustic means [7], [8].

\section{Methodology}

The aim of the study is to develop digital methods and algorithms for automatic quality control of ship's hydroacousticer in areas with different hydrology based on the results of his training on board using hydroacoustic means.

At carrying out of research methods of algorithms simulation of automatic estimation of results of training of the ship's hydroacousticer in a training mode of functioning of on board hydroacoustic means were used.

Theoretical bases of unerroric automatic control for work quality of ship's hydroacousticer on board can and should be considered as digital methods of 
reduction of estimation of results' error of signals digital processing.

"Unerroric" (from Latin "errare") means cumulative application of methods and procedures to reduce the error of information processing methods, [9]. Therefore, the term "unerroric" in relation to such control is defined by a set of digital methods and electronic devices of multilevel estimation of quality of work of ship's hydroacousticer on board by hydroacoustic means [10].

Complexity of watch of the ship's hydroacousticer is characterized by big volumes of the information presented to it and short duration of special trainings of his professional skills, in connection with the limited resource of time. Therefore at times several years are required for development of skills [11], [12]. The efficiency of ship's hydroacousticer training on shore-based simulators depends not only and not so much on the state of their educational and material support, but also on many other conditions. It is necessary to take into account that in this case the initial level of training plays not the least role [13].

The quality of ship's hydroacousticer training in traditional on-site simulation is usually limited by low capabilities of hydroacoustic situation simulation on computer simulators in coastal conditions [14], [15].

However at certification of ship crew, objectivity of decisions of the certifying commission can be increased taking into account results of automatic estimation of performance of the duties by each ship's hydroacousticer on his workplace at operation of on board by hydroacoustic means of a vessel in a training mode [16].

At carrying out of research results of development of following methods (methods of formation of final and intermediate estimations of training results of the ship's hydroacousticer) on the basis of unerroric recurrence algorithms of deductive processing of digital signals are used [17], [18]:

- digital method for calculating the benchmark indicators of the quality of ship's hydroacousticer;

- digital method of comparative analysis of control and normative quality indicators of ship's hydroacousticer;

- digital method of calculation of intermediate estimations of the ship's hydroacousticer solution subtasks of determining the presence of the noise emission source or reflected radiation and its parameters when it solves the problems of noise direction finding and hydroacoustic location;

- digital method of calculation of recommended intermediate assessments of ship's hydroacousticer tasks and recommended final assessment of training results.

These methods allow minimizing and optimizing the composition of control and normative indicators of quality of work of ship's hydroacousticer and recommended intermediate assessments of solution of tasks of noise direction finding and hydrolocation by ship's hydroacousticer in a training mode of functioning of on board hydroacoustic means.

Such methods allowed developing digital algorithms for multilevel assessment of ship's hydroacousticer quality by results of its training directly on board the ship.

\section{Results}

The results of research showed and confirmed the possibility of unerroric quality of ship's hydroacousticer by digital methods of automatic evaluation of the results of his training directly on board.

Carrying out training of ship's hydroacousticer in a training mode of functioning of on board hydroacoustic means on board in real time without application of additional equipment, results of training are registered as the data accessible to digital processing, $\left\{\operatorname{Result}_{n}\left(k_{n}\right)\right\}, k_{n}=1,2,3 \ldots K_{n}, n=1,2,3 \ldots N$, the number of which is determined by the number of noise direction and hydrolocation objects $N$, simulated in the training process, and the number of signs of the result of solving the noise direction or hydrolocation task $K_{n}$, recorded for each $n$-th simulated object, $n=1,2,3 \ldots N$. Training results $\left\{\operatorname{Result}_{n}\left(k_{n}\right)\right\}, \quad k_{n}=1,2,3 \ldots K_{n}, \quad n=1,2,3 \ldots N \quad$ are represented in the form of a matrix of the results of the ship's hydroacousticer $\left\{\right.$ Matrix_data $\left._{n}\left(k_{n}\right)\right\}$, size $N \times K_{N}, k_{n}=1,2,3 \ldots K_{n}, n=1,2,3 \ldots N$, according to the formula (1), where $K_{N}$ is the number of features of the result of the noise direction finding or hydrolocation task, registered for $\mathrm{N}$-th simulated object:

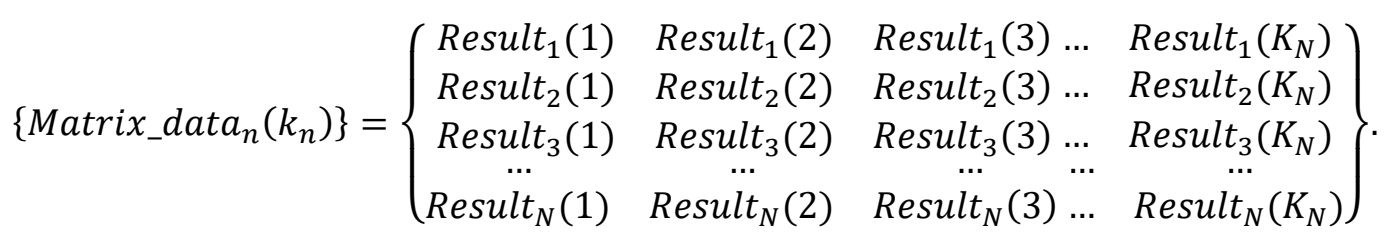


Such matrix provides considerable multilevel control of ship's hydroacousticer competence directly on board of a ship in accordance with the requirements to the ship's hydroacousticer solution of noise direction finding and hydrolocation tasks at change of structure, composition and modes of operation of on board technical and software means in training mode.

The developed digital algorithms for automatic evaluation of training results have a recurrence pyramidal structure with $J$ levels of calculation $k_{j}$-th control parameters and quality control indicators of the ship's hydroacousticer in the training mode of operation of on board hydroacoustic means and production $k_{j}$-th intermediate automatic evaluations of the solution of its hydrolocation tasks $\left\{\right.$ Test $\left._{j}\left(k_{j}\right)\right\}$, $k_{j}=1,2,3 \ldots K_{j}, \quad j=1,2,3 \ldots J$ and $k_{j}$-th intermediate automatic assessments of the solution of its subtasks on the whole set of simulated variants of the signalnoise environment. The structure and composition of necessary and sufficient set of quantitative control and normative indicators are proposed and developed for automatic estimation of results of ship's hydroacousticer training directly on board. Such automatic estimation is performed by method of comparative analysis of necessary and sufficient set of benchmarks and normative indicators by method of directed enumeration of intermediate estimations of results of this analysis. The benchmarks are calculated by the method of finite differences on the basis of the benchmark parameters. The control value of the final automatic evaluation is produced by directed enumeration of all $k_{j}$-th interim assessments $\left\{\right.$ Test $\left._{j}\left(k_{j}\right)\right\}, k_{j}=1,2,3 \ldots K_{j}, j=1,2,3 \ldots J$, and they are produced by directional overshooting of the appropriate $k_{j}$-th interim assessments.

The technical result of the problem decision for automation of estimation of work quality of the ship's hydroacousticer directly on board on results of his training on board is reduction of time and volume of the computing resource required for such training, at simultaneous increase in its efficiency due to increase in number of simulated variants of signalnoise conditions and complexity of simulation models of important, but rare in reality variants of signal-noise conditions.

Multilevel control of ship's hydroacousticer competence directly on board of the ship functions as follows.

At the beginning the recorded results of the ship's hydroacousticer training are entered $\left\{\operatorname{Result}_{n}\left(k_{n}\right)\right\}$, $k_{n}=1,2,3 \ldots K_{n}, n=1,2,3 \ldots N$. Then control parameters and benchmarks of ship's hydroacousticer performance are calculated. On their basis we make the intermediate estimations of ship's hydroacousticer solution of subtasks comprising determination of objects' presence of noise direction finding and hydroacoustics simulated during training and their parameters at solution of tasks of noise direction finding and hydroacoustics. Then intermediate estimations of ship's hydroacousticer solution of the noise direction finding and hydroacoustics tasks are made $\left\{\operatorname{Test}_{j}\left(k_{j}\right)\right\}, k_{j}=1,2,3 \ldots K_{j}, K_{j}=I^{j}, j=1,2,3 \ldots J-1$, $I=2, J=5$ and final evaluation of training results.

Objectivity of multilevel control of ship's hydroacousticer competence is provided by increasing or reducing the number of levels of its pyramidal structure of automatic assessment of the results of such control.

However such model allows describing only formalized process in which characteristic regularities of real process are presented and the factors which are not essential from the point of view of feasibility of the offered structure for automatic evaluation of results of multilevel control in ship's hydroacousticer competence.

The essence of automation of an assessment of ship's hydroacousticer quality by results of his training in a training mode of on board means of noise direction finding and hydroacoustics consist in total application of necessary and sufficient set of control and normative indicators and normative criteria of ship's hydroacousticer quality in this mode and recurrent multilevel pyramidal structure of automatic assessment of his training results for its invariance to changes of structure and operation modes of ship's hydroacousticer.

Automatic estimation of ship's hydroacousticer training results is performed on the basis of methods of calculation and comparative analysis of control and normative indices of its operation quality and directed enumeration of intermediate estimations of results of this analysis. Benchmarks are calculated by the method of finite differences on the basis of control parameters of the results of ship's hydroacousticer training. Final estimation of training results is developed by directed enumeration of estimations of ship's hydroacousticer task solving in the process of training.

Recurrence of the offered multilevel pyramidal structure and optimality of applied sets of control and normative parameters and normative criteria of quality of work of the ship's hydroacousticer provide invariance of this structure to change structure and operating modes of on board technical and software means of training of the ship's hydroacousticer.

The structural diagram of the physical model of the database for automatic evaluation of the results of ship's hydroacousticer training is shown in the Figure 1 .

Structural composition of the database for automatic evaluation of the results of ship's hydroacousticer training is shown in Table 1. 


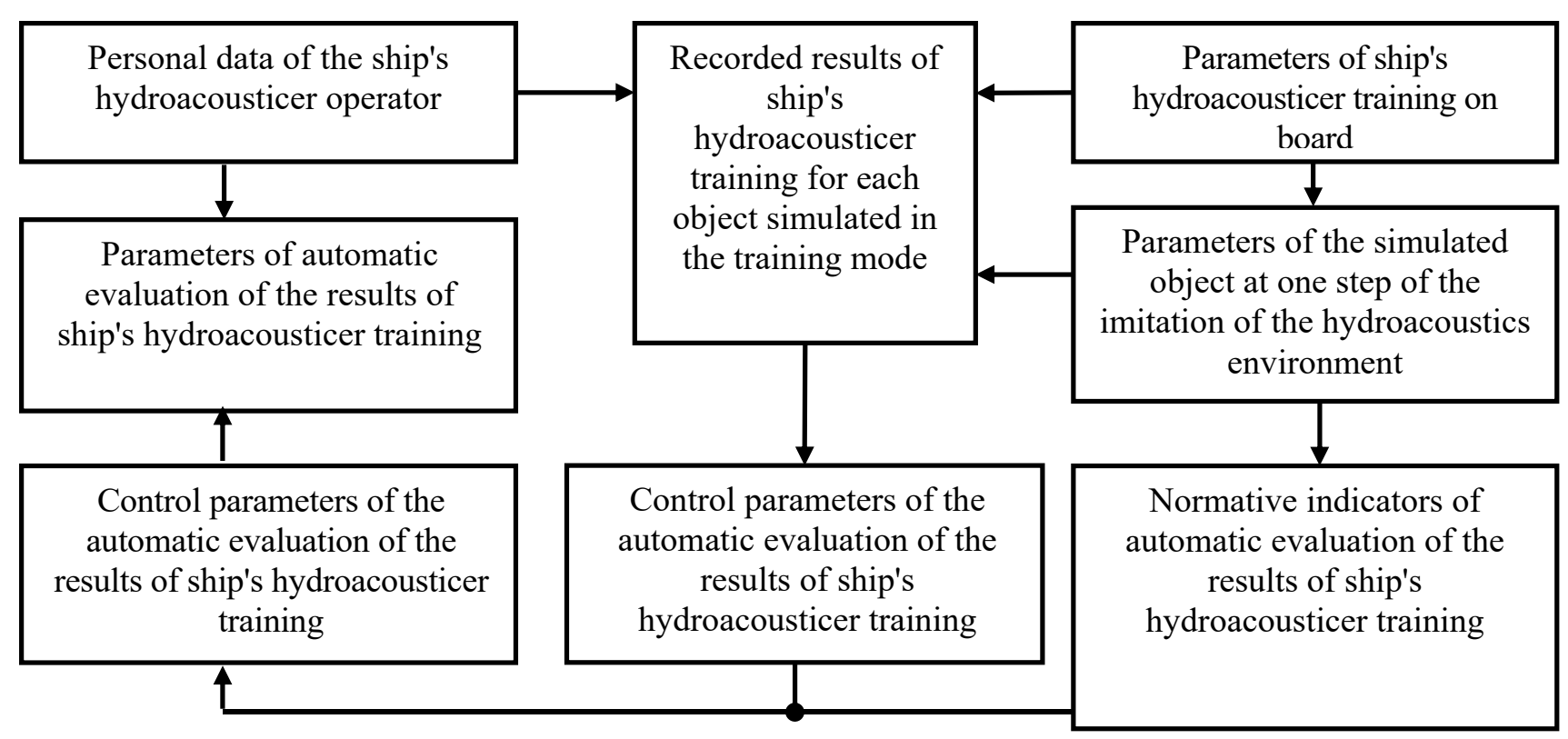

Figure 1. Structural diagram of the physical model of the automatic evaluation database of the results of ship's hydroacousticer training

Table 1. Structural composition of the database for automatic evaluation of results of ship's hydroacousticer training

\begin{tabular}{|c|c|}
\hline Structure name & Structure composition \\
\hline $\begin{array}{l}\text { Personal data of the ship's } \\
\text { hydroacousticer operator }\end{array}$ & Personal profile of the ship's hydroacousticer operator \\
\hline $\begin{array}{l}\text { Parameters of ship's hydroacousticer } \\
\text { training on board }\end{array}$ & $\begin{array}{l}\text { Initial data for the simulation of the hydroacoustic environment in the } \\
\text { training mode }\end{array}$ \\
\hline $\begin{array}{l}\text { Parameters of the object simulated in } \\
\text { one step of the hydroacoustic } \\
\text { simulation }\end{array}$ & Initial data for simulation of an object in one hydroacoustic simulation step \\
\hline $\begin{array}{l}\text { Recorded results of ship's } \\
\text { hydroacousticer training for each } \\
\text { object simulated in the training mode }\end{array}$ & $\begin{array}{l}\text { Numerical values of control parameters of ship's hydroacousticer training } \\
\text { results for each object, simulated in the training mode, to solve the } \\
\text { problems of noise direction finding and hydroacoustics location }\end{array}$ \\
\hline $\begin{array}{l}\text { Control parameters of the automatic } \\
\text { evaluation of the results of ship's } \\
\text { hydroacousticer training }\end{array}$ & $\begin{array}{l}\text { Numerical values of control parameters, automatically calculated by the } \\
\text { results of operation of the ship's hydroacousticer with the objects of noise } \\
\text { direction finding and hydroacoustics simulated in the training mode }\end{array}$ \\
\hline $\begin{array}{l}\text { Benchmarks for automatic evaluation } \\
\text { of ship's hydroacousticer training } \\
\text { results }\end{array}$ & $\begin{array}{l}\text { Calculated numerical values of quality control indicators of the ship's } \\
\text { hydroacousticer operator in the training mode when solving the problems } \\
\text { of noise direction finding and hydroacoustics location in the process of } \\
\text { training }\end{array}$ \\
\hline $\begin{array}{l}\text { Normative indicators of automatic } \\
\text { evaluation of the results of ship's } \\
\text { hydroacousticer training }\end{array}$ & $\begin{array}{l}\text { Numerical values of normative indices and normative criteria of the ship's } \\
\text { hydroacousticer quality in the training mode when solving the problems of } \\
\text { noise direction finding and hydroacoustics in the process of training }\end{array}$ \\
\hline $\begin{array}{l}\text { Parameters of automatic evaluation of } \\
\text { the results of ship's hydroacousticer } \\
\text { training }\end{array}$ & $\begin{array}{l}\text { Final assessment of the results of ship's hydroacousticer training, } \\
\text { intermediate assessments of the ship's hydroacousticer solutions to the } \\
\text { noise direction finding and hydroacoustics tasks, intermediate assessments } \\
\text { of the ship's hydroacousticer solutions to the subtasks of determining the } \\
\text { presence of the simulated object and its parameters when it solves the } \\
\text { noise direction finding and hydroacoustics tasks }\end{array}$ \\
\hline
\end{tabular}

\section{Discussion}

Reliability of recommended by members of the certification committee values of automatic assessment of results within ship's hydroacousticer training is provided by development of a control assessment ("mark" in points) based on the matrix of results of ship's hydroacousticer in the training mode of on board hydroacousticer facilities operation $\left\{\right.$ Matrix_data $\left._{n}\left(k_{n}\right)\right\}, \quad$ size $\quad N \times K_{N}, \quad k_{n}=1,2,3 \ldots K_{n}$, $n=1,2,3 \ldots N$.

Accuracy is recommended to members of the certification commission automatic estimation of results of training of the ship's hydroacousticer 
depends only on set values of standard indicators of his work quality in a training mode of functioning of on board hydroacoustic means.

The offered and developed methods and algorithms of multilevel estimation of work quality of ship's hydroacousticer by results of his training on board locating means allow complicating a simulation model of hydroacoustic conditions fraught with ship accidents.

The reliability of the research results is confirmed by their compliance with the known results of scientific developments [19], [20].

\section{Conclusions}

The proposed and developed methods and algorithms of multilevel estimation of work quality for ship's hydroacousticer by results of his training directly on board hydroacoustics means provide unerroric control of his readiness to estimate extreme variants of hydroacoustic conditions taking into account hydroacoustic noises and noise emission of hydrobionts. Such automation of ship's hydroacoustic performance assessment allows using simulation models even of unlikely but extreme events in different regions of the World Ocean. The pyramidal structure of this assessment allows the use of a significant number of simulation model parameters of undesirable but expected hydroacoustic conditions fraught with ship accidents in abnormal environmental acoustic conditions.

The proposed structure of automatic assessment of the results of ship's hydroacousticer training directly on board the ship during crew certification should provide minimization and optimization of the composition of control and normative indicators of ship's hydroacousticer quality to improve reliability, accuracy and completeness of multilevel assessment of the quality of his work. Therefore, it is required to develop adaptive methods of hardware-software realization of an automatic estimation of results of work of the ship's hydroacousticer which will allow to create and modify software tools of automatic development of value of such estimation on the basis of results of training of the ship's hydroacousticer on board taking into account possible changes of normative indicators of quality of his work.

\section{References}

[1]. Anamova, R. R., Bykov, L. V., \& Kozorez, D. A. (2020). Algorithm for designing professional retraining programs based on a competency approach. Education Sciences, 10(8), 191.

[2]. Kozorez, D. A., Mokrova, M. I., \& Kim, N. V. (2021, June). Formation and research of UAV safety models and observability of objects when monitoring the fire setting. In Journal of Physics: Conference Series (Vol. 1958, No. 1, p. 012025). IOP Publishing.

[3]. Chebotarev, V. E., Brezitskaya, V. V., Kovalev, I. V., Kartsan, I. N., Malanina, Y. N., \& Shemyakov, A. O. (2018, November). Solving navigation-temporal tasks in different coordinate systems. In IOP Conference Series: Materials Science and Engineering (Vol. 450, No. 2, p. 022029). IOP Publishing.

[4]. Kondratenko, L. A., Mironova, L. I., Dmitriev, V. G., Egorova, O. V., \& Shemiakov, A. O. (2019). Investigation of the dynamics of nonlinear mechanical systems with long power lines through digital modeling. Periodico Tche Quimica, 16(33), 668-680.

[5]. Efimov, E., Shevgunov, T., Valaytite, A., \& Sadovskaya, E. (2014, September). Artificial neural network based signal processing for perspective onboard systems. In 29th Congress of the International Council of the Aeronautical Sciences, ICAS 2014 (pp. 1-15).

[6]. Ryapukhin, A. V., Kabakov, V. V., \& Zaripov, R. N. (2019). Risk management of multimodular multiagent system for creating science-intensive high-tech products. Espacios, 40(34), 19.

[7]. Vityazev, V. V., \& Vityazev, S. V. (2007). Digital signal processors TMS320C67x by Texas Instruments. Ryazan: Ryazan State Radio Engineering University.

[8]. Steshenko, V. B. (2007). PLD implementation by firm ALTERA: element base, design system and hardware description languages. Moscow: DODEKA.

[9]. Burova, A. Y., \& Usatenko, T. O. (2021, April). Digital methods of discrete fourier transform, allowing minimizing the number of algorithmic multiplication operations. In Journal of Physics: Conference Series (Vol. 1889, No. 3, p. 032035). IOP Publishing.

[10]. Speransky, V. S., \& Kosichkina, T. P. (2021). Signal microprocessors and their application in communication systems and electronics. Moscow: Hot Line-Telecom.

[11]. Speransky, V. S. (2008). Signal microprocessors and their application in telecommunication systems and electronics. Moscow: Hot Line-Telecom. 
[12]. Steshenko, V. B. (2016). PLD implementation by firm ALTERA: element base, design system and hardware description languages. Moscow: DMKPress.

[13]. Lanne, A. A., \& Merkucheva, T. V. (2009). Filters with double symmetry. Radioelectronics and Communications Systems, 52(5), 256-260.

[14]. Kaplun, D. I., \& Minenkov, D. V. (2009). Synthesis of a new class of NDF without multiplications. Components and Technology, 6, 115120.

[15]. Bogner, R., \& Konstantinidis, A. (1976). Introduction to Digital Filtering. Moscow: World.

[16]. Eremeev, V. P., Matveev, A. G., \& Anufrieva, A. V. (1999). NDF implemented without multiplication. Computer Modeling \& New Technologies, 3, 83-89.
[17]. Goldenberg, L. M., Matyushkin, B. D., \& Polyak, M. N. (1985). Digital Signal Processing: A Guide (Moscow: Radio and communications).

[18]. Eliseev, S. N. (1989). Synthesis of prefilters for constructing NDF with a reduced number of multipliers Higher Education News. Radio electronics, 32(12), 22-28.

[19]. Ukhov, P. A., Borshchenko, D. A., Kabanov, D. D., Bergen, M. E., \& Ryapukhin, A. V. (2021, April). Customization of open-source solutions on the example of the LMS Moodle distance learning platform. In Journal of Physics: Conference Series (Vol. 1889, No. 2, p. 022002). IOP Publishing.

[20]. Kravchenko, T., Shevgunov, T., \& Petrakov, A. (2020, July). On the development of an expert decision support system based on the electre methods. In Computer Science On-line Conference (pp. 552561). Springer, Cham. 